\title{
Cellular Physiology and Biochemistry
}

\section{Apolipoprotein A-V Modulates Insulin Secretion in Pancreatic $\beta$-cells Through its Interaction with Midkine}

\author{
Audrey Helleboid-Chapman ${ }^{1}$, Maxime Nowak1 ${ }^{1}$ Stéphane Helleboid², \\ Emmanuelle Moitrot ${ }^{1}$, Corinne Rommens ${ }^{1}$, Hélène Dehondt ${ }^{1}$, \\ Laurent Héliot ${ }^{3}$, Hervé Drobecq ${ }^{4}$, Jamila Fruchart-Najib ${ }^{1}$ and Jean- \\ Charles Fruchart ${ }^{1}$
}

1 Université Lille Nord de France, Inserm, UDSL and Institut Pasteur de Lille, Lille, ${ }^{2}$ Genfit SA, Loos, ${ }^{3}$ Service généraux, IFR3, Institut de Biologie de Lille, ${ }^{4}$ UMR 8525, Institut de Biologie de Lille

\section{Key Words}

Apolipoprotein A-V • Insulin secretion • Pancreatic $\beta$ cells • Midkine

\begin{abstract}
Apolipoprotein $\mathrm{A}-\mathrm{V}$ is an important determinant of plasma triglyceride level in both humans and mice. This study showed the physiological impact of apoA$V$ on insulin secretion in rat pancreatic $\beta$-cells (INS-1 cells). In order to precise the mechanism of action, binding experiments coupled to mass spectrometry were performed to identify a potential membrane receptor. Results showed an interaction between apoA-V and midkine protein. Confocal microscopy confirmed the plasma membrane co-localisation of this two-proteins after the treatment of INS-1 cells with the apo-AV recombinant protein and indicated that the cell surface midkine could be involved in apoA-V endocytosis, since these two proteins were cotranslocated at the plasma membrane or in the cytosol compartment. This co-localisation is correlated with an increase in insulin secretion in a dose dependant manner during short incubation period. Reduction of midkine expression by small interfering RNA duplexes revealed a decrease in the ability of these transfected
\end{abstract}

\section{KARGER}

Fax +4161306 1234

E-Mail karger@karger.ch

www.karger.com
(C) 2009 S. Karger AG, Basel

1015-8987/09/0246-0451\$26.00/0

Accessible online at:

www.karger.com/cpb cells to secrete insulin in presence of apoA-V. Competition experiments for the apoA-V-midkine binding at the cell surface using antibody directed against midkine is able to influence INS-1 cell function as insulin secretion. Our results showed apoA-V ability to enhance insulin secretion in $\beta$-cells and provide evidence of an internalization pathway involving the midkine as partner.

Copyright @ 2009 S. Karger AG, Basel

\section{Introduction}

Type 2 diabetes is a metabolic syndrome with multifactorial origins involving both defective insulin secretion and impaired insulin sensitivity. It is associated with a marked increase in the risk of cardiovascular diseases, which is typically increased twofold in diabetic men and threefold in diabetic women [1,2]. Lipotoxicity and alteration in glucose homeostasis in liver, muscle, and pancreatic islets plays a crucial role in the development of both $\beta$-cell dysfunction, insulin secretion and insulin resistance [3]. 
Apolipoproteins play a central role in lipid homeostasis and are intimately associated with the cardiovascular disease risk $[4,5]$. Recently, the gene coding for a new apolipoprotein family member, $A P O A 5$, was identified to be an important determinant of plasma triglyceride levels in both humans and mice [6-8]. Apolipoprotein A-V is only synthesized in liver, and data from mice overexpressing or lacking $A P O A 5$ provide direct evidence that this protein is inversely correlated with plasma triglyceride levels [9]. In humans, polymorphisms across the APOA5 locus have been associated with elevated plasma TG concentrations $[6$, 10], familial combined hypertriglyceridemia [11] and increased risk of cardiovascular disease $[12,13]$. ApoA$\mathrm{V}$ appears to activate lipoprotein lipase (LPL)-mediated very low density lipoprotein (VLDL)-triglyceride (TG) hydrolysis, thus accelerates VLDL clearance, and reduces plasma TG by inhibiting hepatic VLDL-TG production [14-17]. Moreover, genetically engineered mice showed that $A P O A 5$ and $A P O C 3$ influence independently, and in an opposite manner, the triglyceride metabolism [18]. It was demonstrated that insulin [19] and thyroid hormone [20] down-regulate the APOA5 gene expression. Moreover, transcription factors implicated in the triglycerides metabolism [21-25] regulate $A P O A 5$ gene. Overall, APOA5 represents a potential therapeutic target for modulation of plasma triglyceride levels.

Midkine is a heparin-binding growth/differentiation factor encoded by a retinoic acid responsive gene $[26,27]$. To act its specific functions in different cell types, midkine binds different proteins such as the low density lipoprotein receptor-related protein (LRP) [28], heparan sulfate proteoglycans and syndecans $[29,30]$, the receptor-like protein-tyrosine phosphatase $\xi$ [31], or the anaplastic lymphoma kinase [32]. This protein is developmentally regulated and involved in angiogenesis, neurogenesis, cell migration and mesoderm-epithelial interactions [33,34]. Midkine is highly expressed in many human cancers [35] and enhances the activity of plasminogen activator (PA) [36]. The signalling system of midkine corresponding to these activities is only partly understood [37, 38]. Kojima et al. suggested that dimer formation is an important step for the biological activity of midkine [39], and Salama et al. demonstrated that the binding of midkine to laminin binding protein precursor leads to nuclear translocation of the molecular complex [40].

Thus, we decide to investigate the physiological impact of apoA-V in the rat pancreatic $\beta$-cells. We provide evidences to demonstrate the apoA-V faculty to enhance the insulin secretion after its interaction with midkine. We perform experiment to show the involvement of midkine and the co-localization with apoA-V to drive this new physiological role. Taken together, our results show the importance of the protein complex apo-AV-midkine, and reveal a new important role for apoA-V in pancreatic $\beta$-cell function and insulin secretion.

\section{Materials and Methods}

\section{Cell Culture and Treatments}

INS-1 cells were maintained in RPMI 1640 medium at $10 \mathrm{mM}$ glucose supplemented with $10 \mathrm{mM}$ HEPES, $10 \%$ heatinactivated fetal calf serum (FCS), L-glutamine, sodium pyruvate, $50 \mu \mathrm{M} \beta$-mercaptoethanol, streptomycin/penicillin in a humidified atmosphere $(5 \% \mathrm{CO} 2)$.

For secretion experiments and interaction study, INS-1 cells were culture, as described by Helleboid-Chapman et al. [41] prior to incubation with apoA-V recombinant protein. The culture medium was replaced with $\mathrm{KRBH}$ containing $5 \mathrm{mM}$ glucose and apoA-V recombinant protein for $30 \mathrm{~min}$ to $3 \mathrm{~h}$.

\section{Affinity binding}

An affinity chromatography step with an activated $\mathrm{CH}$ Sepharose $^{\mathrm{TM}} 4 \mathrm{~B}$ column was introduced after membrane protein extraction. The amino acid sequence of the N-terminal fragment (20-114) of apoA-V used in this work was ATQARKGFWD YFSQTSGDKG RVEQIHQQKM AREPATLKDS LEQDLNNMNK FLEKLRPLSG SEAPRLPQDP VGMRRQLQEE LEEVKARLQP YMAEA. ApoA-V peptide was synthesized by Boc-benzyl chemistry with an Applied Biosystems 433A automated solid-phase peptide synthesizer. The purity of the peptide was monitored by reverse phase high pressure liquid chromatography ( $>95 \%)$. The peptide identity was confirmed by mass spectrometry. Resin and apoA-V peptide were mixed for $2 \mathrm{~h}$ at $37^{\circ} \mathrm{C}$. $15 \mathrm{mg}$ of INS-1 membrane protein was passed through the resin equilibrated with PBS. The resin bound complex was eluted with Tris-glycine buffer $\mathrm{pH} 8(0.2 \mathrm{M})$. Eluted proteins were revealed on $10 \%$ SDS-PAGE and analyzed by mass spectrometry.

\section{Mono-dimensional Electrophoresis and Mass spectrometry}

Desalted proteins were separated by SDS-PAGE using $10 \%$ acrylamide gels containing $1.5 \mathrm{M}$ Tris- $\mathrm{HCl}(\mathrm{pH} 8.8), 10 \%$ SDS, $10 \%$ APS, Temed and run $6 \mathrm{~h}$ at $250 \mathrm{~V}$ using the PROTEAN II XL cell format. Silver staining was performed using the ProteoSilver Plus Silver Stain Kit (Sigma-Aldrich, Inc.). The spots of interest were then excised for identification by mass spectrometry (MALDI-MS) as described by Coutte et al.[42] using Voyager-DE-STR (Applied Biosystem). The peptide masses were matched with the theoretical peptide masses of all proteins of the SWISS-PROT databases. 
Real-time biomolecular interaction analysis using Biacore 3000

Real-time biomolecular interaction analyses were performed by surface plasmon resonance technology using a Biacore 3000 system (Biacore AB, Uppsala, Sweden). All experiments were conducted at $25^{\circ} \mathrm{C}$. The running buffer used was HBS-EP (10 mM Hepes, $\mathrm{pH} 7.4,0.15 \mathrm{M} \mathrm{NaCl}, 3 \mathrm{mM}$ EDTA, and $0.005 \%$ Surfactant P20) at a flow rat of $5 \mu \mathrm{l} / \mathrm{min}$. ApoA-V peptide was coupled to the dextran-modified gold surface of a CM5 sensor chip by amine coupling as described in the BIAcore system manual. The immobilized level was $3500 \mathrm{RU}$ corresponding to $3.5 \mathrm{ng} / \mathrm{mm}^{2}$ of peptide. Samples $(30 \mu \mathrm{l})$ were injected over the chip at a flow rate of $5 \mu \mathrm{g} / \mathrm{min}$, followed by a washing phase with HBS-EP buffer to achieve a steady baseline.

\section{Recombinant apoA- $V$ cloning; expression and purifica-} tion

The coding sequence of human APOA5 [NM_052968] was amplified using the forward primer 5'- ATG CGG ATC CCG GAA AGG CTT CTG GGA CTA - 3' and the reverse primer 5' GAC TAA GCT TTC AGG GGT CCC CCA GAT GGC - 3'. The PCR product was subcloned into pCold I vector (Takara BIO INC) by use of BamH1 and HindIII. The plasmid was propagated in Escherichia coli DH5 $\alpha$ cells. The construct contained the APOA5 coding region without the signal peptide, but with a $\mathrm{His}_{6}$ epitope tag insert upstream. We next transformed Escherichia coli BL21 (DE3) pLysS (Novagen) and propagated isolated colony overnight at $37^{\circ} \mathrm{C}$ with aeration in Terrific Broth (per liter, $12 \mathrm{~g}$ select peptone 140, $23.6 \mathrm{~g}$ yeast extract, $9.4 \mathrm{~g}$ dipotassium dihydrogen, $2.2 \mathrm{~g}$ potassium dihydrogen, $4 \mathrm{ml}$ glycerol) supplemented with $100 \mathrm{mg} / \mathrm{L}$ ampicillin and $34 \mathrm{mg} / \mathrm{L}$ chloramphenicol. We diluted $1 \mathrm{ml}$ of the overnight culture (1:300) in fresh Terrific Broth supplemented with $100 \mathrm{mg} / \mathrm{L}$ ampicillin and incubated the sample at $37^{\circ} \mathrm{C}$ with shaking. When the culture $\mathrm{OD}_{600}$ reached 0.4-0.6, the culture solution was refrigerated at $15^{\circ} \mathrm{C}$ for $30 \mathrm{~min}$ and apoA-V was induced by the addition of $0.15 \mathrm{mM}$ of isopropyl- $\beta$-D-thiogalactopyranoside. After $24 \mathrm{~h}$, cells were harvested by centrifugation, and the pellet was stored at $-80^{\circ} \mathrm{C}$ until needed. Purification of recombinant apoA-V was conducted with Ni-NTA resin (QIAGEN) according to the manufacturer's instructions.

\section{Insulin secretion analysis}

At the end of the treatment, INS-1 cells were washed twice in KRBH. After 20 min, the solution was collected and insulin was measured in the medium by ELISA (Mercodia) using rat insulin as standard. The insulin secretion was expressed as an insulin concentration normalized using the protein.

\section{Preparation of total protein extract and membrane rich protein sample}

Total protein extract was prepared as described by Helleboid-Chapman et al. [41]. For membrane rich protein sample, INS-1 cells were harvest by centrifugation in lysis buffer (50 mM Tris- $\mathrm{HCl} ; 50 \mathrm{mM} \mathrm{NaCl} ; 300 \mathrm{mM}$ sucrose; $1 \mathrm{mM}$ iodoacetamide; $1 \mu \mathrm{M}$ leupeptin; $\mathrm{pH}$ 7.4) and sonicated. After removing nuclei and unlysed cells by centrifugation at $800 \mathrm{~g}$

Apolipoprotein A-V and insulin secretion in pancreatic $\beta$-cells for $10 \mathrm{~min}$, this fraction was sedimented by ultracentrifugation $(100000 \mathrm{~g} ; 1 \mathrm{~h})$. Samples, isolated as pellets, were dissolved in $2 \%$ CHAPS and sonicated. After an equilibration step (10 min) at $37^{\circ} \mathrm{C}$, samples were centrifugated $10 \mathrm{~min}$ at $10000 \mathrm{~g}$. Protein concentrations were determined by Bio-Rad protein assay kit (Bio-Rad).

\section{Confocal microscopy}

After the treatment, INS-1 cells (cultured on coverslips) were fixed with $4 \%[\mathrm{v} / \mathrm{v}]$ paraformaldehyde at room temperature for $40 \mathrm{~min}$. For visualization of midkine and apoA-V distribution, the cells were permeabilized with $0.2 \%$ of Triton X-100 in PBS for $10 \mathrm{~min}$ at room temperature. Before incubation with polyclonal anti-apoA-V antibody (6) at $5 \mu \mathrm{g} / \mathrm{ml}$ for $1 \mathrm{~h}$ at room temperature, cells were blocked with 5\% goat serum in PBS for $15 \mathrm{~min}$ at room temperature. Cells were then incubated with polyclonal anti-midkine antibody (Interchim) at $5 \mu \mathrm{g} / \mathrm{ml}$ for $1 \mathrm{~h}$ at room temperature. Finally, the cells were incubated with Alexa Fluor 488 anti-goat IgG and Alexa Fluor 543 anti-rabbit $\operatorname{IgG}$ at 5 $\mu \mathrm{g} / \mathrm{ml}$ for $1 \mathrm{~h}$ at room temperature. Then, the cover slips were mounted on microscopy slides and analyzed by confocal microscopy (Leica TCS SP2).

\section{Co-immunoprecipitation}

Protein A/G beads slurry were incubated with monoclonal apoA-V antibody [14] at $4^{\circ} \mathrm{C}$ for $2 \mathrm{~h}$ with gentle rotation. After centrifugation, a mix of apoA-V peptide and INS-1 proteins was added and incubated at $4{ }^{\circ} \mathrm{C}$ for $4 \mathrm{~h}$ with gentle rotation. The protein $\mathrm{A} / \mathrm{G}$ bead were washed with HBS buffer three times and subjected to boiling in Laemmli buffer (Biorad) containing $10 \%$ dithiothreitol for $5 \mathrm{~min}$ to release and denature the proteins, which were then separated by SDS-PAGE for immunoblotting.

\section{Western Blotting}

Immuboblotting were performed as described by Helleboid-Chapman et al. [41]. For midkine detection, the polyclonal rabbit anti-midkine antibody was used at the dilution of $(1: 2000)$.

\section{siRNA Transfection}

Transfection assays of INS-1 cells were conducted with siPORT Amine (Ambion) according to the manufacturer's instructions. Cells were transfected with a Silencer Negative Control siRNA (Ambion) or with a RNA targeting the midkine sequence (only sense sequence is shown): 5'-GAC AAG GUG AAG AAG GGC ATT- 3'. Cells were harvested 48h after adding siRNA duplexes and examined for kindlerin expression by PCR amplification.

\section{Gene expression analysis}

Total RNA was prepared from INS-1 cells using RNeasy ${ }^{\mathrm{TM}}$ Total RNA Kit (Qiagen, Germany), treated with DNase I RNase free (Qiagen) and reverse-transcribed with random hexamers using the Omniscript RT kit. The resulting cDNA product was subsequently PCR amplified. Primers were designed using Vector NTI Suite software (Informax) based on sequence data avail- 
Fig. 1. (A) CH Sepharose 4B column separation of INS-1 membrane proteins. Fractions eluted at the void volume of the column are numbered from 1 to 4 . (B) Sensorgram of interaction in real time of the purified fractions (1-4) on the immobilized apoA$\mathrm{V}$ peptide. Real time biomolecular interaction analyses were performed by surface plasmon resonance technology using a Biacore 3000 system.

able through Genbank: rat midkine (GenBank accession no NM_030859): forward 5'-GCA GCA CCGAAG TTT CTT CC-3', reverse 5'CTG CCC TTC TTC ACC TTG TC-3'.

\section{Statistical analyses}

Statistical analysis was performed using t-tests and $\mathrm{p}<0.05$ was considered statistically significant. Statistical differences from controls are indicated with asterisks $(*, p<0.05 ; * *, p<0.01$ and $* * *, \mathrm{p}<0.001)$.

\section{Results}

Interaction of apoA-V with the cell surface-expressed midkine

To identify a potential apoA-V receptor, apoA-V binding proteins were isolated by affinity chromatography on a CH Sepharose 4B column from membrane proteins. Four peaks were detected and subjected to dialyze (Fig. 1A). To examine the binding of these fractions, we analyzed the interaction of apoA-V with the membrane fractions by Biacore 3000 technology (Fig. 1B). ApoA$\mathrm{V}$ peptide was found to physically interact at high affinity with the fraction 3 . This fraction was analyzed by SDSPAGE and proteins were submitted to trypsin digestion followed by MALDI TOF mass spectrometry. One major band corresponding to a molecular mass of approximately $17 \mathrm{kDa}$ was identified as midkine.

\section{ApoA-V co-immunoprecipitates with midkine}

To confirm apoA-V-midkine interaction, we used coimmunoprecipitation method to verify whether apoA-V forms a complex with midkine. As a result, midkine was detected in the precipitates of total and membrane protein extract after $30 \mathrm{~min}$ or $2 \mathrm{~h}$ of incubation (Fig. 2). Upon SDS-PAGE, a major $34 \mathrm{kDa}$ band was isolated and we supposed that it could correspond to the dimer form of midkine. Indeed, it was shown that midkine serves as a substrate for tissue transglutaminase, which readily yielded SDS- and $\beta$-mercaptoethanol-resistant multimers (39). The proportion of midkine in the co-precipitates was more important in total protein extract than in membrane fraction. This observation could be explained by the fact



B


Fig. 2. Co-immunoprecipitation of apoA-V and midkine. INS1 total and membrane protein extracts pre-incubated with apoA$\mathrm{V}$ were immunoprecipitated with apoA-V monoclonal antibodies bound to protein $\mathrm{A} / \mathrm{G}$ agarose and subjected to immunoblotting analysis using polyclonal midkine antibodies. Pre-incubation steps with apo A-V were performed for $30 \mathrm{~min}$ [lane 2] or 2h [lane 3-5] with: $500 \mu \mathrm{g}$ [lane 2-3] and $1 \mathrm{mg}$ [lane 4] of total protein or $500 \mu \mathrm{g}$ of membrane protein [lane 5].

that midkine was distributed in different subcellular compartments. In conclusion, using coimmunoprecipitation, we have confirmed the interaction between apoA-V and midkine in INS-1 cells.

ApoA-V and midkine co-localize in the membrane subcellular compartment

To confirm the interaction of the exogenously added apolipoprotein $\mathrm{A}-\mathrm{V}$ to the cell surface expressed midkine,

Helleboid-Chapman/Nowak/Helleboid/Moitrot/Rommens/Dehondt/ Héliot/Drobecq/Fruchart-Najib/Fruchart 




Fig. 3. Co-localization study of apoA-V with midkine using confocal microscopy. As control, the figure (A) shows the distribution of midkine [red] in INS-1 cells. Figures (B) and (C) show the distribution of midkine [red] and apoA-V [green] in INS-1 cells treated for $30 \mathrm{~s}$ with apoA-V recombinant protein at the concentration of $400 \mathrm{ng} / \mathrm{ml}$. Figure (D) is merge image of (B) and (C). Figure (E) shows the distribution of apoA-V after $10 \mathrm{~min}$ of incubation with apoA-V. Figure (F) and (G) show the new distribution of apoA-V [green] and midkine [red] in INS-1 cells treated for $1 \mathrm{~h}$ with apoA-V at the concentration of $400 \mathrm{ng} / \mathrm{ml}$. Figure $(\mathrm{H})$ is merge image of $(\mathrm{F})$ and $(\mathrm{G})$.

confocal microscopy studies were performed. We demonstrated that, in INS-1 cells, endogenous midkine was mainly detectable in the cytoplasm and slightly in the plasma membrane (Fig. 3A). INS-1 cells were incubated with apoA-V peptide at $37^{\circ} \mathrm{C}$ for $30 \mathrm{~s}$ before immunolocalization experiments. The results showed that midkine was immediately concentrated in distinct spots at the plasma membrane (Fig. 3B), and it co-localized with apoA-V spots (Fig. 3D). There was a slight signal of apoA-V in the cytoplasm, suggesting entry during the incubation period at $37^{\circ} \mathrm{C}$ (Fig. 3C). Co-localization of the two proteins is represented by yellow color (Fig. 3D) when figure $3 \mathrm{~B}$ and $3 \mathrm{C}$ were merged. After $10 \mathrm{~min}$, an enrichment of apoA-V in the plasma membrane was observed (Fig. 3E). After $1 \mathrm{~h}$ exposure to apoA-V recombinant protein, we examined a marked increase in apoA-V cytoplasmic staining, indicative from the transition from the plasma membrane to the cytoplasm (Fig. $3 \mathrm{~F}$ ). After this treatment, a fraction of midkine remained in plasma membrane, but there was a notable increase in midkine expression in a more cytoplasmic staining pattern (Fig. 3G). Co-staining INS-1 cells with midkine and apoA-V antibodies revealed a differential responsiveness (Fig. $3 \mathrm{H}$ ). After this $1 \mathrm{~h}$ treatment with apoA-V

Apolipoprotein A-V and insulin secretion in pancreatic $\beta$-cells recombinant protein, a significant loss of coincidence of midkine and apoA-V was observed in the cytoplasmic compartment. It should be noted that no green or red signal was detected when only secondary antibody was used in these experiments (not shown).

ApoA-V stimulates insulin secretion in INS-1 cells In order to investigate the potential physiological role of apoA-V in pancreatic $\beta$-cells, we tested the ability of apoA-V recombinant protein to stimulate insulin secretion release. ApoA-V is present in human serum and circulates at much lower concentrations than other apolipoproteins, such as apoA-I. O'Brien et al. [43] observed human serum apo $\mathrm{A}-\mathrm{V}$ concentrations ranging from 24 to $406 \mu \mathrm{g} / \mathrm{L}$ with a mean value in normolipidemic persons of $157 \mu \mathrm{g} / \mathrm{l}$. Thus, we used two concentrations of apoA-V recombinant protein not exceeding the physiological concentrations to explore its biological function in pancreatic $\beta$-cells (Fig. 4A). Interestingly, the incubation of INS-1 cells with apoA-V recombinant protein for $30 \mathrm{~min}$ and $1 \mathrm{~h}$ induced insulin secretion (respectively 3.64 and 2.59 fold-induction). However, this effect was not significant at $3 \mathrm{~h}$ of incubation. ApoA-V recombinant protein significantly increased insulin secretion in a dose de- 


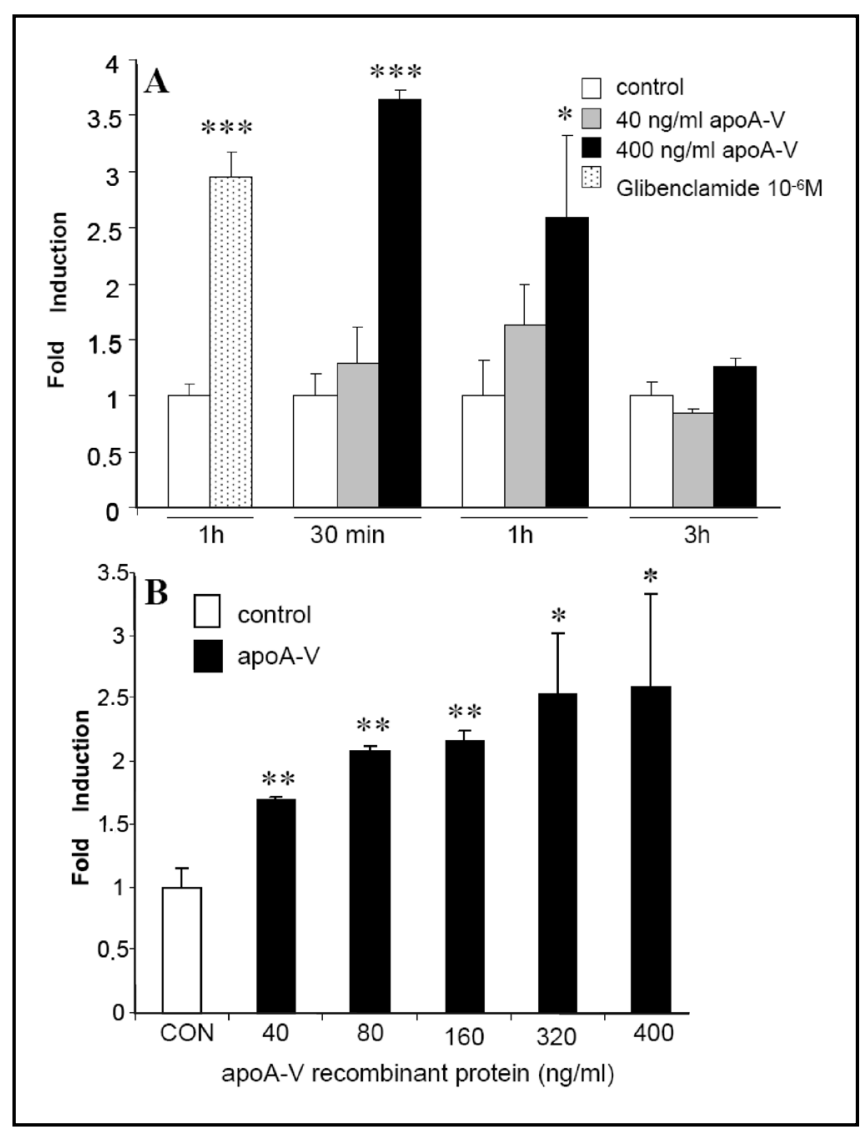

Fig. 4. Effect of apoA-V recombinant protein (A, B) on insulin secretion in INS-1 cells. (A) Cells were cultured overnight in RPMI medium containing $5 \mathrm{mM}$ glucose before they were stimulated with apoA-V recombinant protein at the concentrations of 40 or $400 \mathrm{ng} / \mathrm{ml}$ for different time periods [30 min; $1 \mathrm{~h}$ or $3 \mathrm{~h}$ ]. Insulin secretion was measured by ELISA and normalized to cell protein content. (B) Dose response of insulin secretion in INS-1 cells upon $1 \mathrm{~h}$-exposure to apoA-V recombinant protein [filled bars, $n=3$ ] or vehicle [open bar, $n=3$ ]. Values are means \pm S.E. $[\mathrm{n}=4]$.

pendant manner ( 0 to $400 \mathrm{ng} / \mathrm{ml}$ ) to reach a 2.59 foldinduction at the maximal concentration (400 ng/ml) after 1h of incubation (Fig. 4B). These results showed that apoA-V could be implicated in the stimulation of insulin secretion in INS-1 cells up to $1 \mathrm{~h}$ incubation period.

The binding of apoA-V to midkine is involved in insulin secretion in INS-1 cells

To assess the function of midkine, we employed small interfering RNA (siRNA) duplexes to reduce the expression of midkine in INS-1 cells. Midkine gene expression was reduced (approx. 0.8 fold) in INS-1 cells
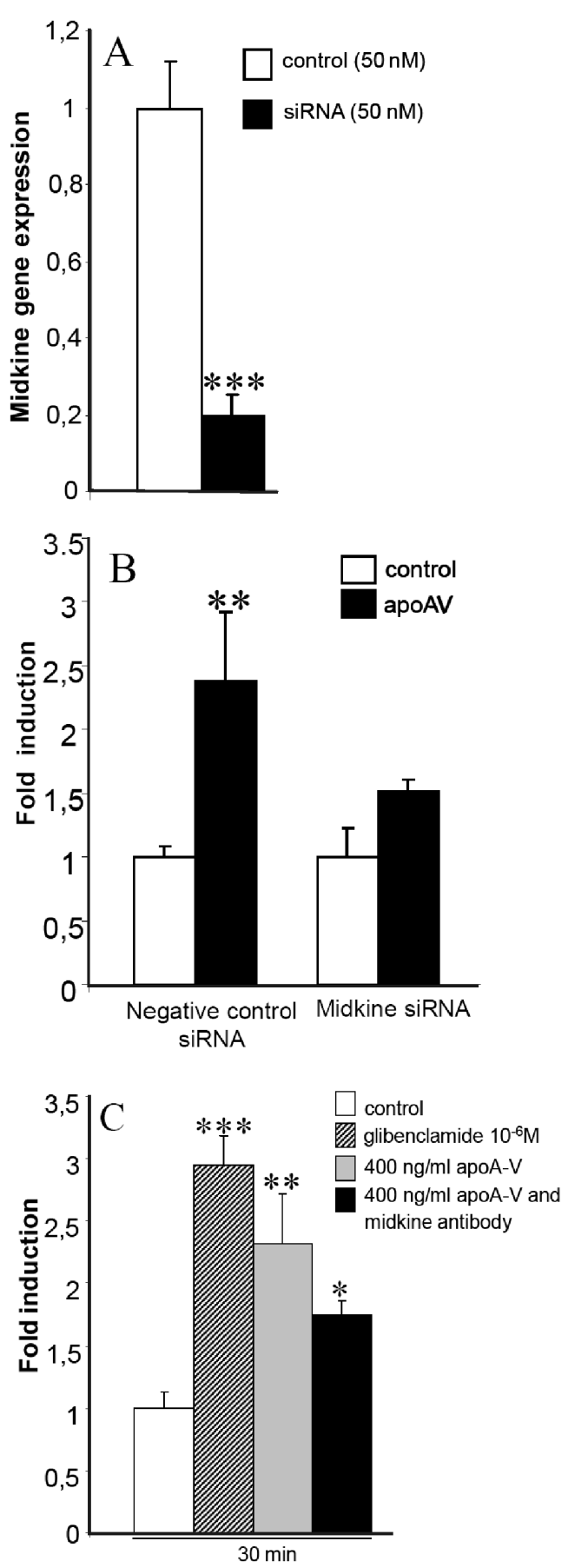

Fig. 5. The effect of midkine knock-down on insulin secretion in INS-1 cells stimulated with apoA-V recombinant protein. (A) Rat midkine mRNA was analyzed by semiquantitative RT-PCR normalized to $28 \mathrm{~S}$. (B) INS-1 cells were transfected with siRNA control or siRNA midkine before incubation with apoA-V recombinant protein $[400 \mathrm{ng} / \mathrm{ml}]$ for $30 \mathrm{~min}$ in $5 \mathrm{mM}$ glucose. Insulin secretion was measured by ELISA and normalized to cell protein content. (C) The effect of midkine blocking on insulin secretion in INS-1 cells stimulated with apoA-V recombinant protein.

Helleboid-Chapman/Nowak/Helleboid/Moitrot/Rommens/Dehondt/ Héliot/Drobecq/Fruchart-Najib/Fruchart 
transfected with the midkine siRNA as compared with cells transfected with a scramble siRNA as shown in Fig. 5A. 48h after transfection of the siRNA duplexes, cells were incubated with apoA-V recombinant protein $(400 \mathrm{ng} / \mathrm{ml})$ for $30 \mathrm{~min}$. Insulin secretion analyses revealed a decrease in the ability of midkine siRNA cells to secrete insulin compared to scramble siRNA cells upon stimulation with apoA-V recombinant protein (Fig. 5B). We concluded that reduction in midkine gene expression level affects cell response to apoA-V. To examine whether the interaction apoA-V-midkine is involved in insulin secretion, INS- 1 cells were incubated for 5 min with midkine antibody and $30 \mathrm{~min}$ in presence of apoA-V recombinant protein. We observed that anti-midkine antibody affected insulin release induced by apoA-V treatment (Fig. 5C). In conclusion, all together, these results suggest that apoAV stimulates insulin secretion in INS-1 cells through binding to midkine.

\section{Discussion}

Glucose-stimulated insulin secretion and $\beta$-cell growth are important facets of pancreatic islet $\beta$-cell biology. Factors that modulate these processes are of great interest for the potential treatment of Type 2 diabetes. Dysregulation of this process as alteration in lipid metabolism can affect both insulin sensitivity and $\beta$-cell function. Apolipoprotein A-V is an important determinant of lipid metabolism. In human, the role of $A P O A 5$ gene in plasma triglyceride concentration has been shown in several studies [6, 44-47]. However, the impact of the apoA$\mathrm{V}$ on $\beta$-cell function has not been examined.

In this study, we identified a protein that interacts with apolipoprotein $\mathrm{A}-\mathrm{V}$ in rat pancreatic $\beta$-cells (INS-1 cell line) and examined the role of apoA-V as insulin secretion inducer. As an approach to identify cell surface molecules which bind to the apoA-V, we used affinity chromatography in combination to mass spectrometry. Herein, we report that apoA-V binds to midkine, a heparin-binding multifunctional protein. Midkine was first identified as the product of a retinoic acid-responsive gene that is up-regulated in the differentiation system of embryonal carcinoma cells [26, 27]. Its important roles have been implicated in various aspect of biology, however the mechanisms of midkine corresponding to these activities are only partly understood.

To test the hypothesis that the apoA-V have specific effect on $\beta$-cell biology, insulin secretion was measured in INS-1 cells after incubation with apoA-V

Apolipoprotein A-V and insulin secretion in pancreatic $\beta$-cells recombinant protein. In this model, apoA-V increased insulin secretion in a dose dependant manner during $1 \mathrm{~h}$ of incubation. Antibody directed against midkine were used to investigate competition experiments for the apoAV-midkine binding at the cell surface. As expected, the incubation with the anti-midkine antibody decreased insulin secretion stimulated by apoA-V. These results showed that the cross-linking of midkine and apoA-V on the cell surface is able to influence INS-1 cell function such as insulin secretion. We conclude that the binding of these two proteins is functionally important. To confirm the requirement of midkine in stimulation of insulin secretion, we employed a RNA interference approach targeting midkine expression. This strategy resulted in a decrease in midkine expression of $80 \%$ after $48 \mathrm{~h}$, which attenuated the ability of apoA-V to stimulate insulin secretion. These experiments provide evidence that both midkine and apoA-V are required to enhance insulin secretion, this underlying the importance of their interaction in this physiological function.

The kinetic of exogenous apoA-V subcellular localization was studied by exposing INS-1 cells to apoA-V recombinant protein during $30 \mathrm{~s}$ to $1 \mathrm{~h}$. After $30 \mathrm{~s}$ of incubation, apoA-V was mainly detected on the cell surface. The amount of internalized apoA-V increased in the plasma membrane until $10 \mathrm{~min}$. Moreover, this subcellular localization changed during the time course and apoA$\mathrm{V}$ was translocated to the cytoplasmic compartment. The internalized apoA-V was detected not homogeneously, reflecting cytoplasmic but also probably vesicular compartment localizations. In the same experiment, we observed the membrane recruitment of midkine in response to apoA-V treatment. After $30 \mathrm{~s}$, apoA-V and midkine were mostly co-localized on the cell surface. However, this membrane localization disappeared. ApoA-V and midkine were progressively co-translocated to the cytoplasm. It has been reported that midkine exert its effect by binding to cell surface receptor [28, 31]. Recently, Shibata et al. [48] showed that exogenous midkine was endocytosed by cultured mouse L cells and then transported to the nucleus, and the nuclear translocation is necessary for the anti-apoptotic activity of midkine. The present findings indicate that the cell surface midkine is involved in apoA-V endocytosis, since these two proteins were co-translocated in the cytosol compartment. In INS-1 cells, midkine may provide a mechanism of cytoplasmic translocation implying signalling receptor as it was reported by Muramatsu et al. [28] for the low density lipoprotein receptor-related protein, which belongs to the low density lipoprotein (LDL) receptor family. 
Here, we demonstrated that the co-localization apoA-V-midkine occurs in the pancreatic $\beta$-cell and led to a significant increase of the insulin secretion. Recent studies focused on apoA-V were investigated to better understand the mechanism of its action on the TG-rich lipoprotein hydrolysis. Fruchart-Najib et al. [14] and Schaap et al. [17] have reported in 2004 that apoA-V regulates the TG levels through an increased hydrolysis of TG-rich lipoprotein by LPL lipolysis. In accordance with these findings, Lookene et al. [49] and Merkel et al. [15] proposed in 2005 a possible mechanism explaining its inverse correlation with plasma TG levels. Indeed, authors showed that apoA-V lipid complexes bind heparin and may promote their association with cell surface heparan sulfate proteoglycans. As LPL is bound to cell surface proteoglycans in physiological conditions, they concluded that apoA-V accelerates plasma hydrolysis of TG-rich lipoproteins by interaction with proteoglycan-bound LPL. Recently, new findings suggest an additional mechanism for the modulation of TG levels, focus on a direct interaction of apoA-V with the major LDL receptor family member (LRP). Interestingly, whatever hypothesis considered, both proposed mechanisms suggest a link between apoA-V and midkine, which bind heparan sulfate proteoglycans and LRP [2830]. This could explain the apoA-V and midkine co-localization at the plasma membrane of INS-1 and the two protein co-immunoprecipitation in membrane protein fraction.

In 2005, Chiu et al. [50] showed that the V150M polymorphism in the APOA5 gene had an independent influence on first and second phases insulin response. Although the biological consequence of this polymorphism remains to be determined, the $V 150 M$ polymorphism in the $A P O A 5$ gene is a genetic marker for $\beta$-cell function. Our results have led to the first described physiological role for apoA-V in pancreatic $\beta$-cells by increasing insulin secretion and provide evidence of an internalization pathway involving the midkine as partner.

\section{Abbreviations}

APOA5 (the human gene); apoA-V (the human protein); apoa5 (the rodent gene); TG (triglyceride); LPL (lipoprotein lipase); LDL (low density lipoprotein); VLDL (very low density lipoprotein); LRP(LDL receptor family member).

\section{Acknowledgements}

This work was supported by research grants from Leducq foundation and Astra Zeneca.

\section{References}

- Haffner SM, Lehto S, Ronnemaa T, Pyorala K, Laakso M: Mortality from coronary heart disease in subjects with type 2 diabetes and in nondiabetic subjects with and without prior myocardial infarction. N Engl J Med 1998;339:229234.

$>2$ Wilson PW: Diabetes mellitus and coronary heart disease. Am J Kidney Dis 1998;32:S89-100.

$>3$

Boden G, Shulman GI: Free fatty acids in obesity and type 2 diabetes: defining their role in the development of insulin resistance and beta-cell dysfunction. Eur J Clin Invest 2002;32 Suppl 3:14-23.

Breslow JL: Apolipoprotein genetic variation and human disease. Physiol Rev 1988;68:85-132.
Zannis VI, Breslow JL: Genetic mutations affecting human lipoprotein metabolism. Adv Hum Genet 1985;14:125-215, 383126.

Pennacchio LA, Olivier M, Hubacek JA, Cohen JC, Cox DR, Fruchart JC, Krauss RM, Rubin EM: An apolipoprotein influencing triglycerides in humans and mice revealed by comparative sequencing. Science 2001;294:169-173. van der Vliet HN, Sammels MG, Leegwater AC, Levels JH, Reitsma PH, Boers W, Chamuleau RA: Apolipoprotein A-V: a novel apolipoprotein associated with an early phase of liver regeneration. J Biol Chem 2001;276:4451244520 . van der Vliet HN, Schaap FG, Levels JH, Ottenhoff R, Looije N, Wesseling JG, Groen AK, Chamuleau RA: Adenoviral overexpression of apolipoprotein A-V reduces serum levels of triglycerides and cholesterol in mice. Biochem Biophys Res Commun 2002;295:1156-1159. Jakel H, Nowak M, Helleboid-Chapman A, Fruchart-Najib J, Fruchart JC: Is apolipoprotein A5 a novel regulator of triglyceride-rich lipoproteins? Ann Med 2006;38:2-10.

10 Pennacchio LA, Olivier M, Hubacek JA, Krauss RM, Rubin EM, Cohen JC: Two independent apolipoprotein A5 haplotypes influence human plasma triglyceride levels. Hum Mol Genet 2002;11:3031-3038. 
-11 Ribalta J, Figuera L, Fernandez-Ballart J, Vilella E, Castro Cabezas M, Masana L, Joven J: Newly identified apolipoprotein $\mathrm{AV}$ gene predisposes to high plasma triglycerides in familial combined hyperlipidemia. Clin Chem $>_{2}$ 2002;48:1597-1600

$\$ 12$ Hubacek JA, Skodova Z, Adamkova V, Lanska V, Poledne R: The influence of APOAV polymorphisms (T-1131 $>$ C and S19 $>$ W) on plasma triglyceride levels and risk of myocardial infarction. Clin Genet 2004;65:126-130.

13 Lai CQ, Demissie S, Cupples LA, Zhu Y, 22 Adiconis X, Parnell LD, Corella D, Ordovas JM: Influence of the APOA5 locus on plasma triglyceride, lipoprotein subclasses, and CVD risk in the Framingham Heart Study. J Lipid Res 2004;45:2096-2105.

$>14$ Fruchart-Najib J, Bauge E, Niculescu LS, Pham T, Thomas B, Rommens C, Majd Z, Brewer B, Pennacchio LA, Fruchart JC: Mechanism of triglyceride lowering in mice expressing human apolipoprotein A5. Biochem Biophys Res Commun 2004;319:397-404.

15 Merkel M, Loeffler B, Kluger M, Fabig N, Geppert G, Pennacchio LA, Laatsch A, Heeren J: Apolipoprotein AV accelerates plasma hydrolysis of triglyceriderich lipoproteins by interaction with proteoglycan-bound lipoprotein lipase. J Biol Chem 2005;280:21553-21560.

-16 Oliva CP, Pisciotta L, Li Volti G, Sambataro MP, Cantafora A, Bellocchio A, Catapano A, Tarugi P, Bertolini S, Calandra S: Inherited apolipoprotein A$\mathrm{V}$ deficiency in severe hypertriglyceridemia. Arterioscler Thromb Vasc Biol 2005;25:411-417.

$\checkmark 17$ Schaap FG, Rensen PC, Voshol PJ, Vrins $C$, van der Vliet HN, Chamuleau RA, Havekes LM, Groen AK, van Dijk KW: ApoAV reduces plasma triglycerides by inhibiting very low density lipoproteintriglyceride (VLDL-TG) production and stimulating lipoprotein lipase-mediated VLDL-TG hydrolysis. J Biol Chem 2004;279:27941-27947.

18 Baroukh N, Bauge E, Akiyama J, Chang J, Afzal V, Fruchart JC, Rubin EM, Fruchart-Najib J, Pennacchio LA: Analysis of apolipoprotein A5, c3, and plasma triglyceride concentrations in genetically engineered mice. Arterioscler Thromb Vasc Biol 2004;24:1297-1302.

19 Nowak M, Helleboid-Chapman A, Jakel H, Martin G, Duran-Sandoval D, Staels B, Rubin EM, Pennacchio LA, Taskinen MR, Fruchart-Najib J, Fruchart JC: Insulin-Mediated Down-Regulation of Apolipoprotein A5 Gene Expression through the Phosphatidylinositol 3-Kinase Pathway: Role of Upstream Stimulatory Factor. Mol Cell Biol 2005;25:1537-1548.
Prieur X, Huby T, Coste H, Schaap FG, Chapman MJ, Rodriguez JC: Thyroid hormone regulates the hypotriglyceridemic gene APOA5. J Biol Chem 2005;280:27533-27543.

Genoux A, Dehondt H, HelleboidChapman A, Duhem C, Hum DW, Martin G, Pennacchio LA, Staels B, FruchartNajib J, Fruchart JC: Transcriptional regulation of apolipoprotein A5 gene expression by the nuclear receptor RORalpha. Arterioscler Thromb Vasc Biol 2005;25:1186-1192.

Jakel H, Nowak M, Moitrot E, Dehondt H, Hum DW, Pennacchio LA, FruchartNajib J, Fruchart JC: The liver X receptor ligand T0901317 down-regulates APOA5 gene expression through activation of SREBP-1c. J Biol Chem 2004;279:45462-45469.

Lind U, Nilsson T, McPheat J, Stromstedt PE, Bamberg K, Balendran C, Kang D: Identification of the human ApoAV gene as a novel RORalpha target gene. Biochem Biophys Res Commun 2005;330:233-241.

24 Prieur X, Coste H, Rodriguez JC: The human apolipoprotein $\mathrm{AV}$ gene is regulated by peroxisome proliferator-activated receptor-alpha and contains a novel farnesoid X-activated receptor response element. J Biol Chem 2003;278:2546825480 .

Vu-Dac N, Gervois P, Jakel H, Nowak M, Bauge E, Dehondt H, Staels B, Pennacchio LA, Rubin EM, FruchartNajib J, Fruchart JC: Apolipoprotein A5, a Crucial Determinant of Plasma Triglyceride Levels, Is Highly Responsive to Peroxisome Proliferator-activated Receptor alpha Activators. J Biol Chem 2003;278:17982-17985.

Kadomatsu K, Tomomura M, Muramatsu $\mathrm{T}$ : cDNA cloning and sequencing of a new gene intensely expressed in early differentiation stages of embryonal carcinoma cells and in mid-gestation period of mouse embryogenesis. Biochem Biophys Res Commun 1988;151:1312-1318.

27 Tomomura M, Kadomatsu K, Nakamoto M, Muramatsu H, Kondoh H, Imagawa $\mathrm{K}$, Muramatsu T: A retinoic acid responsive gene, MK, produces a secreted protein with heparin binding activity. Biochem Biophys Res Commun 1990;171:603-609.

-28 Muramatsu H, Zou K, Sakaguchi N, Ikematsu S, Sakuma S, Muramatsu T: LDL receptor-related protein as a component of the midkine receptor. Biochem Biophys Res Commun 2000;270:936941.
Mitsiadis TA, Salmivirta M, Muramatsu T, Muramatsu H, Rauvala H, Lehtonen E, Jalkanen M, Thesleff I: Expression of the heparin-binding cytokines, midkine (MK) and HB-GAM (pleiotrophin) is associated with epithelial-mesenchymal interactions during fetal development and organogenesis. Development 1995;121:37-51.

-30 Nakanishi T, Kadomatsu K, Okamoto T, Ichihara-Tanaka K, Kojima T, Saito H, Tomoda Y, Muramatsu T: Expression of syndecan-1 and -3 during embryogenesis of the central nervous system in relation to binding with midkine. J Biochem (Tokyo) $1997 ; 121: 197-205$

31 Maeda N, Ichihara-Tanaka K, Kimura T, Kadomatsu K, Muramatsu T, Noda M: A receptor-like protein-tyrosine phosphatase PTPzeta/RPTPbeta binds a heparin-binding growth factor midkine. Involvement of arginine 78 of midkine in the high affinity binding to PTPzeta. J Biol Chem 1999;274:12474-12479.

Stoica GE, Kuo A, Powers C, Bowden ET, Sale EB, Riegel AT, Wellstein A: Midkine binds to anaplastic lymphoma kinase (ALK) and acts as a growth factor for different cell types. J Biol Chem 2002;277:35990-35998.

Beecken WD, Kramer W, Jonas D: New molecular mediators in tumor angiogenesis. J Cell Mol Med 2000;4:262-269.

Zhang N, Deuel TF: Pleiotrophin and midkine, a family of mitogenic and angiogenic heparin-binding growth and differentiation factors. Curr Opin Hematol 1999;6:44-50.

- 35 Tsutsui J, Kadomatsu K, Matsubara S, Nakagawara A, Hamanoue M, Takao S, Shimazu H, Ohi Y, Muramatsu T: A new family of heparin-binding growth/differentiation factors: increased midkine expression in Wilms' tumor and other human carcinomas. Cancer Res 1993;53:1281-1285.

Kojima S, Muramatsu H, Amanuma H, Muramatsu T: Midkine enhances fibrinolytic activity of bovine endothelial cells. J Biol Chem 1995;270:9590-9596. Takada T, Kinkori T, Muramatsu H, Hayakawa A, Torii S, Muramatsu T: Midkine, a retinoic acid-inducible heparin-binding cytokine, is a novel regulator of intracellular calcium in human neutrophils. Biochem Biophys Res Commun 1997;241:756-761.

Owada K, Sanjo N, Kobayashi T, Mizusawa H, Muramatsu H, Muramatsu T, Michikawa M: Midkine inhibits caspase-dependent apoptosis via the activation of mitogen-activated protein kinase and phosphatidylinositol 3-kinase in cultured neurons. J Neurochem 1999;73:2084-2092. 
39 Kojima S, Inui T, Muramatsu H, Suzuki Y, Kadomatsu K, Yoshizawa M, Hirose S, Kimura T, Sakakibara S, Muramatsu T: Dimerization of midkine by tissue transglutaminase and its functional implication. J Biol Chem 1997;272:94109416.

40 Salama RH, Muramatsu H, Zou K, Inui T, Kimura T, Muramatsu T: Midkine binds to $37-\mathrm{kDa}$ laminin binding protein precursor, leading to nuclear transport of the complex. Exp Cell Res 2001;270:13-20.

Helleboid-Chapman A, Helleboid S, Jakel H, Timmerman C, Sergheraert C, Pattou F, Fruchart-Najib J, Fruchart JC: Glucose regulates LXRalpha subcellular localization and function in rat pancreatic betacells. Cell Res 2006;16:661-670.

$>42$ Coutte L, Antoine R, Drobecq H, Locht C, Jacob-Dubuisson F: Subtilisin-like autotransporter serves as maturation protease in a bacterial secretion pathway. Embo J 2001;20:5040-5048.
43 O'Brien PJ, Alborn WE, Sloan JH, Ulmer M, Boodhoo A, Knierman MD, Schultze AE, Konrad RJ: The novel apolipoprotein A5 is present in human serum, is associated with VLDL, HDL, and chylomicrons, and circulates at very low concentrations compared with other apolipoproteins. Clin Chem 2005;51:351-359.

44 Baum L, Tomlinson B, Thomas G: APOA5-1131T $>$ C polymorphism is associated with triglyceride levels in Chinese men. Clin Genet 2003;63:377-379. Endo K, Yanagi H, Araki J, Hirano C, Yamakawa-Kobayashi K, Tomura S: Association found between the promoter region polymorphism in the apolipoprotein A-V gene and the serum triglyceride level in Japanese schoolchildren. Hum Genet 2002;111:570-572.

Martin S, Nicaud V, Humphries SE, Talmud PJ: Contribution of APOA5 gene variants to plasma triglyceride determination and to the response to both fat and glucose tolerance challenges. Biochim Biophys Acta 2003;1637:217225.
Talmud PJ, Hawe E, Martin S, Olivier M, Miller GJ, Rubin EM, Pennacchio LA, Humphries SE: Relative contribution of variation within the APOC3/A4/A5 gene cluster in determining plasma triglycerides. Hum Mol Genet 2002;11:3039-3046.

Shibata Y, Muramatsu T, Hirai M, Inui T, Kimura T, Saito H, McCormick LM, Bu G, Kadomatsu K: Nuclear targeting by the growth factor midkine. Mol Cell Biol 2002;22:6788-6796.

9 Lookene A, Beckstead JA, Nilsson S, Olivecrona G, Ryan RO: Apolipoprotein A-V-heparin interactions: implications for plasma lipoprotein metabolism. J Biol Chem 2005;280:25383-25387.

Chiu KC, Chiu YF, Boyadjian AA, Fernando S, Kwan C, Chuang LM: Impact of apolipoprotein A5 polymorphisms on insulin sensitivity and beta-cell function. Pancreas 2005;30:328-332. 